\title{
Financial disclosure and the Board: A case for non-independent directors
}

\author{
Yuri Biondi, Pierpaolo Giannoccolo and Antoine Rebérioux*
}

\begin{abstract}
In listed companies, the Board of directors has ultimate responsibility for information disclosure. The conventional wisdom is that director independence is an essential factor in improving the quality of that disclosure. In a sense, this approach subordinates expertise to independence. We argue that effective certification may require firm-specific expertise, in particular for intangible-intensive business models. However, this latter form of expertise is negatively related to independence as it is commonly measured and evaluated. Accordingly, there exists an optimal share of independent directors for each company, related to the level of intangible resources.
\end{abstract}

Key words: Board of directors, information disclosure, accounting, intangible resources

JEL classifications: G30, M21, D80, M41

\footnotetext{
Yuri Biondi (yuri.biondi@polytechnique.edu), Tenured Research Fellow, CNRS-Ecole Polytechnique (Preg CRG). Pierpaolo Giannoccolo (pierpaolo.giannoccolo@unibo.it), Assistant Professor, University of Bologna, Department of Economics. Antoine Rebérioux (antoine.reberioux@u-paris10.fr, corresponding author), Assistant Professor, University Paris Ouest Nanterre, EconomiX. Research funded by the FP6 European Program 'Reflexive governance in the public interest'. Paper presented to the Conference "Governance, Intangibles and Corporate Social Responsibility", Collegio S. Chiara, University of Siena, 29 September 2008; to the EAEPE 2008 Conference, University of Rome 3-7 November 2008; to the Euram 2009 Conference, Liverpool, 1114 May 2009 (nominated as best paper of the corporate governance track); to the American Accounting Association Annual Meeting, New York, August 1-5, 2009.
} 


\section{INTRODUCTION}

Over the last decade, a succession of high-profile corporate scandals and bankruptcies (Enron, Worldcom, Parmalat, Lehman Brothers, AIG, etc.) has put the control of public companies' executive management firmly in the spotlight. From this point of view, information disclosure is usually regarded as the cornerstone of an effective institutional design, especially when (minority) shareholders are remote from the company and its business model (Berle and Means 1932).

Yet, as regulators and academics have long recognized, relevant and reliable information disclosure depends crucially on corporate governance (Brown 2007): who is accountable for the production and certification of financial and non-financial reporting? Any attempt to answer this question necessarily involves getting inside the black box of public companies in order to investigate the set of relationships that exist between a firm's various constituencies (Cohen, Krishnamoorthy and Wright 2004). Invariably, any such analysis points to the responsibility of the Board of directors, which acts as strategic counsellor, facilitator of network relations and monitor of business affairs (see e.g. Johnson, Daily and Ellstrand 1996). This latter role notably includes hiring and firing the chief executive officer (CEO) and other executive managers, determining executive pay and supervising the firm's reporting and disclosure procedures. The Board achieves this last objective by recommending the external auditor to shareholders and by interfacing with the external auditors, the internal auditors and management. In addition, in almost all jurisdictions, the Board should certify financial statements and other public information ${ }^{1}$. In this way, it helps

\footnotetext{
${ }^{1}$ In the U.S. case, existing signature requirements for reports filed under the 1934 Exchange Act and the 2002 Sarbanes Oxley Act demand that at least a majority of directors sign annual reports, taking specific responsibility for them even beyond formal compliance with accounting standards. The importance of the Board in shaping the overall quality of public company reporting is regularly reaffirmed by the Securities and Exchange Commission (Brown 2007), whose primary function is to ensure adequate disclosure. A conspicuous example is provided by the W. R. Grace Report (1997) - a section 21(a) Report - that notes: 'the Commission considers it essential for board members to move aggressively to fulfil their responsibilities to oversee the conduct and performance of management and to ensure that the company's public statements are candid and complete'. In the British case, the Combined Code on Corporate Governance (2003) - listing rules require public companies to report on how they apply the principles set out in the Code or to provide an explanation - clearly states: "Non-executive directors should scrutinise the performance of management in meeting agreed goals and objectives and monitor the reporting of performance. They should satisfy themselves on the integrity of financial information and that financial controls and systems of risk management are robust and defensible' (p.5). In the French case, legal duties for directors are set out in the Code de commerce: article L.232 indicates that in listed companies the Board must certify the financial statements.
} 
alleviate the agency problem by facilitating the regular release of unbiased accounting information by managers to those who hold a stake in the firm (including shareholders), thus reducing the information asymmetry between insiders and outsiders.

The crucial question, then, is the following: what characteristics of the Board are likely to improve its performance in this certification role? The 'conventional wisdom' (Bhagat and Black 1999), both among regulators and corporate governance scholars, is that director 'independence' is the essential attribute. As Cunningham (2007) notes, the now standard response to corporate crises is to look to independent directors to provide greater transparency, with independence being defined or proxied through a set of formal criteria (de jure or formal independence). The Sarbanes Oxley Act, passed in 2002, is no exception, requiring that audit committees be comprised solely of independent members. The objective is clear: de jure independence should help to limit conflicts of interests, thus improving the performance of directors in their monitoring activity. In the case of certification, independence guarantees that the decision not to validate biased information is made without collusion or delay.

Some recent developments suggest that this 'conventional wisdom' is gradually being challenged, with expertise being increasingly recognized as a decisive attribute, especially for the audit committee (Cunningham 2007). In particular, the Sarbanes Oxley Act introduced a path-breaking provision that requires that all audit committee members be financially literate and that at least one person be a financial expert (section $407)^{2}$. The idea is intuitive: generic expertise in accounting and finance, acquired through education or professional activity, potentially increases the relevance and reliability of disclosure and improves the quality of financial and non-financial reporting that the Board must certify.

However, we argue that for certain types of business models, effective, trustworthy certification requires firm-specific in addition to generic expertise. This will be the case whenever intangible resources, related to innovation, knowledge and human resources, are significant drivers of the firm's performance potential. The main reason is that these intangible resources, by their very nature, raise serious problems of valuation

\footnotetext{
${ }^{2}$ In the UK, the Combined Code (2003; see supra, note 1) also contains a recommendation of financial expertise.
} 
(recognition and measurement) for outsiders and often lack efficient market pricing (Lev 2001). From an accounting point of view, the dilemma is then the following: either these resources should be deliberately ignored, thereby exacerbating informational asymmetry between insiders and outsiders, or specific reporting rules should be applies, which requires firm-specific expertise to be efficiently implemented by directors.

The problem is that firm-specific expertise is likely to be negatively related with de jure independence, as commonly defined and proxied. This is not the case with generic expertise, which can easily be combined with independence. Thus the focus on independence may have had, and may still be having, adverse consequences, since it reduces the ability of Board members to acquire and certify firm-specific information, whether financial or non-financial, in circumstances that are likely to be significant in contemporary businesses. To some extent, this analysis sheds some light on a longstanding empirical puzzle, namely the observation that independence has a negligible or even negative effect on company performance (Klein 1998; Dalton, Daily, Ellstrand and Johnson 1998; Bhagat and Black 1999; Klein, Shapiro and Young 2005; Bhagat, Bolton and Romano 2008) $)^{3}$.

More precisely, we show that there exists an optimal share of independent directors for each company, related to the core characteristics of the firm in question. We derive two main implications from this analysis. On the one hand, 'super-majority' Boards (that is Boards with at least $80 \%$ of de jure independent members) appear to be attractive devices only in very limited cases - contrary to what is usually called for. As stated by Roberts, McNulty and Stiles (2005), the main contributors to the Higgs Report that led to the revision, in November 2003, of the British Combined Code: 'the advocacy by institutional investors, policy advisors and the business media for greater non-executive independence may be too crude or even counter-productive' (p.S19). On the other hand, 'grey' or 'affiliate' directors (that is, directors who do not meet the standard criteria of independence while not being member of the firm's executive management) may enhance the overall quality of control, including certification.

\footnotetext{
${ }^{3}$ See e.g. Bhagat, Bolton and Romano (2008, p.1850): 'Board independence, however, is negatively and significantly related to contemporaneous, next year's, and next two years' operating performance. This result is surprising, especially considering the recent emphasis that has been placed on board independence by the stock exchanges' amended listing requirements post-Enron; however, it is consistent with prior literature on boards'.
} 
Our analysis complements and extends Osterloh and Frey's (2006) argument, who insist on the role that may be played by insiders with firm-specific knowledge in responding to critical issues of corporate governance. We expressly focus on the monitoring role of the Board, and what is undoubtedly at the core of this role, namely the supervision of information flows from the firm to outside stakeholders, including investors on the (stock) market. By so doing, we connect this corporate governance issue with accounting theory and practice. This connection is suggested by Gordon (2007) who argues that the growing volume of information disclosed by listed companies makes insiders and other firm-specific experts less valuable as corporate directors. On the contrary, our analysis stresses the importance of their inside perspective for improving the quality of disclosure and control.

The rest of the paper is organised as follows. The second section examines the information set available to shareholders, seeking to make accurate financial decisions concerning the firm. The main point here is that the set of business information to be disclosed is jointly constituted of market-driven and firm-specific information. The latter type of information is likely to be relevant in business models where performance is driven mainly by intangible resources. The third section focuses on accounting as the main device through which information (both market-driven and firm-specific) is transmitted from inside the firm to its external environment. In particular, we argue that the certification of financial statements by directors with specific business knowledge becomes increasingly important as intangible resources grow in significance. The fourth section focuses, therefore, on the Board of directors and in particular on the Board characteristics likely to produce efficient certification. The existence of a trade-off between two of these characteristics (de jure independence and firm-specific expertise) is emphasized, and helps to deliver an optimal share of independent directors, depending on the relative importance of intangibles resources in the business model. Section five provides a summary of the argument by way of conclusion. 


\section{THE INFORMATIONAL BASIS OF STOCK MARKET INVESTMENT AND CORPORATE DISCLOSURE}

This section examines the informational basis of financial decision-making in the stock market (1.) and relates this basis to the kind of resources (tangible versus intangible) involved at the firm level (2.).

\section{Financial investors and the relevant information set}

Both standard setters - in particular the US Financial Accounting Standard Board (FASB) and the International Accounting Standard Board (IASB) that regulates EUlisted corporate groups - and a majority of accounting scholars now share the view that the primary function of financial reporting is the provision of information to investors. This information enables them to assess the amounts, timing and uncertainty of future cash flows from their investment in corporate shares or debt securities (SFAC $n^{\circ} 1, \S 37$; IASB Framework, §15). Under this financial 'decision usefulness paradigm' of accounting (Hitz, 2007), accounting relevance is defined as the degree of correspondence between required and disclosed information.

Basic financial theory provides some clear-cut answers as to the kind of information on a firm (as opposed to macroeconomic evidence) required by investors to make accurate financial decisions. A first set of assumptions concerns the characteristics of investors. Investors are expected to be rational (they maximize the expected utility of lifetime consumption) and capable of borrowing or lending without constraints, at a given interest rate $i$. Individual preferences are then irrelevant (consumption and investment decisions can be separated) and the sole information required by investors is the ability of the firm to deliver future revenue. The 'fundamental value' of the firm $(F V)$ can then be defined as the discounted value of (expected) net future cash flows to its residual claimers:

$$
F V=\sum_{i=1}^{\infty} \frac{R_{t}^{e}}{(1+i)^{t}}
$$

where $R^{e}{ }_{t}$ is the expected net cash flow at time $t$, and $i$ the usual discount rate. 
A second set of assumptions concerns the origin of these (expected) cash flows, that is, the type of "resources" ${ }^{4}$ deployed by the production process. In the simplest case, the set of resources is composed only of tangible, separable resources. Under these conditions, the fundamental value of the firm is expected to be equal to the sum, properly discounted, of the net contributions of these resources to the fundamental value of the whole firm (see e.g. Brealey and Myers 2005, Ch.9):

$$
F V=\sum_{t=1}^{\infty} \frac{r_{1, t}^{e}}{(1+i)^{t}}+\sum_{t=1}^{\infty} \frac{r_{2, t}^{e}}{(1+i)^{t}}+\ldots+\sum_{t=1}^{\infty} \frac{r_{n, t}^{e}}{(1+i)^{t}}=\sum_{j=1}^{n} \sum_{t=1}^{\infty} \frac{r_{j, t}^{e}}{(1+i)^{t}}
$$

where $r_{j, t}^{e}$ is the expected net contribution of resource $a_{j}$ at time $t, j=(1, \ldots, n)$. In this way, the firm is merely a collection of $n$ resources and its fundamental value equals the sum of the fundamental values of its resources.

A third set of assumptions relates to the existence of an efficient pricing for each of the firm's resources as well as for its shares. Suppose that every resource is traded in a competitive, liquid market by rational investors. Then, the equilibrium price $\left(p_{j}\right)$ of a resource $a_{j}$ equals its fundamental value, so that no mispricing occurs. (Capital) markets are then fundamentally 'efficient', in the sense that the price of a resource fully and correctly incorporates all available information on the ability of this resource to generate net revenue through time (Fama 1970; Malkiel 1992). The Efficient Capital Market Hypothesis $(\mathrm{ECMH})$ implies that a firm's share price $(P)$ is equal to its fundamental value $^{5}$. If all the resources as well as the firm's shares are traded in (fundamentally) efficient markets, then equation (2) becomes:

$$
F V=P=\sum_{j=1}^{n} p_{j}
$$

To sum up, on the basis of this set of hypotheses concerning investors, the economic nature of the firm and the functioning of markets, a firm's (fundamental) value $(F V)$ can be derived from the market value $\left(p_{j}\right)$ of all its resources $\left(a_{j}\right)$. This list of prices constitutes the whole set of information on the company required by financial market

\footnotetext{
${ }^{4}$ We prefer not to use the term assets because of its special accounting meaning: an asset is a resource that is recognised on the left-hand side of the balance sheet.

${ }^{5}$ Note that this identification of fundamental and market values for a share is a typical result (and not just an hypothesis) of the Capital Asset Pricing Model (CAPM), the standard model of equilibrium asset pricing, where all investors share homogenous beliefs concerning the joint distribution of (future) payoffs on the share (Sharpe 1964; Lintner 1965).
} 
investors in order to value a firm properly, that is, to assess the structure of its future cash flows.

This conceptual framework clearly relies on restrictive assumptions and may be questioned from at least two different viewpoints. Let $\Phi$ define the set (or vector) of information available to investors to assess a firm's fundamental value. The first critique refers to the efficiency of the stock market with respect to the treatment of the information set $\Phi$, i.e. to the dynamics of share price formation. Some investors may not be fully rational, as recognised by behavioural finance and cognitive psychology (Shleifer 2000): either their preferences depart from the expected utility framework or their beliefs are subject to overconfidence, conservatism or irrational exuberance. Even assuming the coexistence of rational and non-rational investors, limits to arbitrage (e.g. constraints on short-selling) may prevent an alignment of fundamental and market values (Barberis and Thaler 2003) ${ }^{6}$. In sum, and whatever the reasons, some may question the ability of the market to provide efficient pricing, in the sense of the ECMH: market prices may not efficiently 'exploit' the relevant information set $\Phi$.

The second viewpoint, and the one we will emphasize, seeks to elucidate the precise contents of $\Phi$, rather than its exploitation by investors. While keeping the fundamental value perspective - the idea that investors are primarily interested in the firm's ability to deliver future performance - consideration should be given to the possibility that the individual contributions of each resource cannot be clearly identified (problems occur at the level of equation 2), or that some resources may not be traded in a competitive, liquid market (problems occur at the level of equation 3). In these cases, the relevant information set should encompass items of information that are not encapsulated or subsumed into a market price. For instance, the firm's ability to provide a particular form of training for its workforce may be a relevant driver of performance potential, but there is no available reference market pricing for it. Accordingly, investors should generally rely upon an available set of information that is partly endogenously generated by market pricing (market-driven) and partly generated by other sources of information, external to the market, which are specific to the firm. Then the whole set of relevant

\footnotetext{
${ }^{6}$ Moreover, when models of asset pricing with heterogeneous beliefs are used, then the identity of market price and fundamental value is no longer guaranteed (Stout 2003).
} 
(decision-useful) information $\Phi$ results from and comprises two main subsets of information:

$$
\Phi=\left(p_{h} ; y_{k}\right), h=1, \ldots, l \text { and } k=1, \ldots, m
$$

where $p_{h}$ is the subset of market-driven information and $y_{k}$ is the subset of non-market, firm-specific information.

\section{The case of intangible resources}

So-called intangible resources are a typical example of resources that do not usually meet the criteria of marketability, while being important drivers of performance for contemporary business firms. Intangibles are non-physical (they are not embodied in a physical medium) and non-financial (they do not provide any legally-enclosed revenue) and provide future benefits (Kim 2007). Generally speaking, the following expenditures are associated with the development and maintenance of such intangibles: (i) spending on information and communication technologies (hardware, telecommunication infrastructure and software); (ii) spending on research and development (R\&D, both scientific and non-scientific) and patents; (iii) spending on the development and maintenance of brands and trademarks; (iv) spending on workforce training in firmspecific capabilities and improvements in labor organization (total quality management, job rotation, just-in-time, team working and so on).

The evidence strongly suggests that intangible resources are a crucial component of long-term performance or profit (Villalonga 2004). At the macro level, measurements using US data lead to the conclusion that, at the end of the 1990s and the beginning of the 2000s, private investment in intangibles roughly equaled investment in tangibles, representing around 10\% of domestic output (Nakamura 2003; Corrado, Hulten and Sichel 2006). Corrado et al (2006) find that, for the period 1995-2003, intangibles accounted for $27 \%$ of annual growth, a percentage equal to tangibles for the same period. At the micro level, countless studies have examined the role in firm performance played by R\&D (Griliches 1994), new technologies (Black and Lynch 2001) or innovative organizational practices (Caroli and Van Reenen 2001). 
Overall, complementarities are shown to be pervasive in a business model driven by intangibles (see e.g. Antonelli 2001; OECD 2006). Complementarities occur when combining two different resources yields greater output than using them separately. When resource prices are held constant, this combination symmetrically reduces total costs. Empirical studies stress the joint contribution provided by intangibles relating to workforce training, R\&D and organizational innovation. With regard to information and communication technologies (ICTs) and new work practices, for example, Breshnahan, Brynjolfsson and Hitt (2002) observe that ICTs have a stronger impact on productivity in firms that simultaneously adopt decentralized forms of labor organization. As far as training and new work practices are concerned, various studies provide evidence of a correlation between training efforts and labor reorganization, suggesting that such a combination does indeed improve performance (see e.g. Lynch and Black 1998). Finally, Scicchitano (2007) provides evidence of complementarities between R\&D and on-the-job training.

Because of such complementarities, intangibles do not fit the particular framework assumed by equations 2 and 3 regarding the separability and marketability of individual contributions (see also Ijiri 1967, p.58; Lev 2001). Accordingly, proper information on intangible resources is not generally accessible through markets but belongs rather to the subset of firm-specific information.

To sum up, in a world of complete (meaning one market per resource) and perfect (in the sense of fundamentally efficient) markets, the information set would be reduced to a list of market prices. In this case, the certification provided by the Board merely consists in assessing the firm's collection of resources in line with external market prices. However, if these restrictive assumptions are relaxed, entity-specific information is required by outside stakeholders. Yet the firm-specific subset $\Phi$ raises challenging questions. Market prices are public, objective information, easily accessible once generated by the market. In addition, interpretation of them is unambiguous: everyone agrees that a resource whose price goes from $6 \$$ up to $12 \$$ costs exactly twice as much as previously. In contrast, the statement that the quality of workforce training was substantially improved may be interpreted in different ways by different actors. Furthermore, the meaning and reliability of this statement also depends on the characteristics of the agent making the claim. The difference between the two subsets $p_{h}$ and $y_{k}$ is nicely captured by the distinction between 'hard' and 'soft' information, as 
proposed by Stein (2002) or Petersen (2004) ${ }^{7}$. Accordingly, the quality of firm-specific information depends critically on the context in which it is discovered and disclosed, and the certifiers of this information are a critical part of the process of disclosure. Thus the likelihood of firm-specific information being biased or incomplete cannot be regarded as negligible: even if the (stock) market is efficient, the available information set may not be fully relevant to investors. They may make the most efficient use of the information set that is available, but this set may be too narrow or biased to provide a suitable basis for assessing the firm's ability to deliver performance over the long run.

For these reasons, firm-specific information is typically provided by the accounting system in accordance with the enforced conventions, standards and rules on which the disclosure and reporting processes are based. From this point of view, the accounting system constitutes one of the cognitive prerequisites that enable investors to effectively play the stock exchange over time, leveling the market playing field by providing common knowledge on the business entity's performance and position over time (Shubik 1993; Sunder 2002).

\footnotetext{
${ }^{7}$ According to Petersen (2004. p. 7), 'for the information to be hard, the meaning is dependent only upon the information which is sent. [...] With soft information the context under which it is collected and the collector of the information are part of the information. It is not possible to separate the two'.
} 


\section{PUBLIC DISCLOSURE OF INFORMATION: THE ROLE OF ACCOUNTING}

This section analyses the special role played by accounting in the disclosure of information (1.) and then examines the specific case of intangibles (2.).

\section{Market basis versus entity-specific basis for accounting}

Interestingly, the previous distinction between the two subsets making up the information vector $\Phi$ is mirrored in accounting, in which there are two main models or bases: a 'market basis' and an 'entity-specific basis' (Anthony 2004, p.25 and f.; IASB $2005)^{8}$. These models differ primarily in the methods used to represent business resources in financial statements.

Accounting for a resource on a 'market basis' involves measuring it at its exchange price under competitive market conditions, reflecting the market's expectations as to the amounts, timing and uncertainty of future cash flows discounted at market rates of return for commensurate risk. The market price is considered as the resultant of the whole set of future cash flows imputable to the resource $j$ :

$$
p_{j}=\sum_{t=1}^{\infty} \frac{\stackrel{+}{e}^{r_{j, t}-r^{e}}}{(1+i)^{t}}
$$

where ${ }^{+} r_{j, t}^{e}$ is the (expected) inflow at time $t,{ }^{-} r_{j, t}^{e}$ is the (expected) outflow at time $t$, both flows being imputable to the resource $j$ having a market price $p_{j}$, with $i$ the discount rate of reference.

The market basis for accounting therefore applies a 'stock method' (measurement on the basis of a discounted prevision of a stock of wealth). Known also as 'fair value' or 'marked-to-market' accounting, this stock method may be performed in two different ways. In the first, it is assumed that the measurement has been (efficiently) performed by a market; in this case, the market price is used as a direct measure of the value, keeping accounting items in line with external market reference prices. Alternatively, the measurement is internally generated through accounting models, on the ground that

\footnotetext{
${ }^{8}$ This article uses 'firm-specific' and 'entity-specific' as equivalent expressions.
} 
no efficient pricing is directly accessible but may be mimicked by relying on certain assumptions concerning future cash flows and proper discount rates ${ }^{9}$.

In contrast, the method of accounting for a resource on an 'entity-specific basis' makes use of expectations and data from the reporting entity. When representing a resource, the entity-specific method applies a 'flow method' that recognizes past and current costs (rather than future net revenue) using conventions on the continued usefulness of the underlying resource for the enduring economy of the firm. So called "historical cost" accounting is a typical example of this measurement basis, where resources are accounted for through the flow of monetary expenditures $\left(r_{h}\right)$ related to that resource or activity:

$$
C_{j}=\sum_{h=1}^{n} \bar{r}_{j, h}
$$

where $\mathrm{C}$ is the cumulated amount of expenditures ${ }^{-} r$ that have been disbursed to period $h \subset(1, \ldots, n)$ to develop and maintain the resource $j$. Contrary to the stock method, no legal or physical medium is required, since the resource does not have to be marketable. Only the existence of imputable expenditures and appropriate conventions of continuity and usefulness apply.

Entity-specific basis is not limited to the measurement of resource through so-called 'historical' cost accounting, but also encompasses the broad set of qualitative statements, like narratives and classifications, that seek to provide firm-specific information and/or forward-looking information. This type of firm-specific, less quantitative information has grown rapidly over recent decades. In the case of US-listed companies, Gordon (2007) documents a large increase in the quantity of firm-specific information delivered, in particular, through Form 10-K, from about 75 pages in 1985 to 166 in 2004. Of particular interest is the growth of the 'Management's Discussion and Analysis' (MD\&A), that should, according to the SEC (Securities Act Rel. no. 6711, April 1987) 'focus specifically on material events and uncertainties known to management that would cause reported financial information not to be necessarily indicative of future operating results or of future financial conditions'. According to

\footnotetext{
${ }^{9}$ The reliance of marked to model on specific information and data that the market is by definition unable to validate, raises doubts as to whether this measurement technique really belongs to the market basis, rather than to the entity-specific basis.
} 
Gordon (2007), the average MD\&A expanded from about 5 pages in 1985 to 24 in 2004. In France, entity-specific basis of accounting is provided for by the Rapport de gestion ('Business report', Code de commerce article L.225-102-1), and the complementary disclosure on corporate social responsibility established by the New Economic Regulation (NER) Act of May 2001 (Law 2001-420). This set of reports delivers forward-looking information (through a document on the general situation of the company and its expected evolution) as well as a document detailing how the social and environmental consequences of corporate activity are dealt with. Needless to say, this information is firm-specific, soft in nature and lacking in adequate market reference pricing.

To conclude, by referring to expenditures incurred by the firm or to qualitative information specific to it, the entity-specific basis of accounting clearly refers to the firm-specific subset of the $\Phi$ vector, while the marked-to-market basis of accounting refers to the market subset.

\section{Accounting for intangibles}

The regulatory treatment of intangible resources offers a conspicuous example of the consequences of these two accounting bases. A first possibility is to favor a market basis for the measurement of these resources: the international accounting standard for intangible assets (IAS 38, §39) adopts this solution, linking informational reliability to market-based estimates of value. Therefore, this accounting standard denies asset recognition and measurement to a number of expenditures related to resources that lack a proper market basis, such as 'research activities aimed at obtaining new knowledge; search for, evaluation and final selection of, applications of research findings or other knowledge; search for alternatives for materials, devices, products, processes, systems or services; and the formulation, design, evaluation and final selection of possible alternatives for new or improved materials, devices, products, processes, systems or services' (IAS 38, §56). Generally speaking, internally generated intangibles, such as core research activities, are not capitalized as assets, even though 'entity's costing 
systems can often measure reliably the cost of generating an intangible asset internally, such as salary and other expenditure incurred' (IAS 38, §62). ${ }^{10}$

Thus whenever intangible assets are important drivers for future performance, the regulatory decision to confine the accounting reporting to market-basis methods is likely to lead to investment decisions based on an incomplete set of information ${ }^{11}$. Thus, the importance of intangibles should pave the way to consider other, entity-specific accounting methods. A pure historical cost accounting system that capitalizes and amortizes the expenditures (including deferred charges) linked to internally generated intangibles as depreciable assets is a convenient way to effect this measurement. Evidence of this treatment existed in European accounting systems and regulations before the adoption of International Financial Reporting Standards (see e.g. in the French case: Plan Comptable Général, articles 361-1, 361-2 and 361-3) as well as in the current Japanese accounting standards on R\&D Cost and Intangible Assets.

Furthermore, this entity-specific accounting representation is not limited to financial figures (quantitative information), but may also include classifications and narrative explanations (qualitative information) disclosed according to accepted principles of informational veracity. An interesting case of such a system as applied to intangibles is provided by the French regulation on social reporting ('bilan social'), which requires large companies to establish a conventionally standardized set of non-financial measures on workforce-related issues such as remuneration, training, and security at work (Law 77-769, July 1977). This set is not publicly disclosed, but is available to all employees and their representatives. Another example is the voluntary disclosure devoted to environmental and social responsibility issues that is increasingly provided

\footnotetext{
${ }^{10}$ Other examples are provided by IAS 38 - Intangible Assets, §6, 1998 version and IAS38 - Intangible Assets, §63-64. On this point, see Eckstein (2004).

${ }^{11}$ This point is fully acknowledged by the $\operatorname{OECD}(2006, \mathrm{p} .7)$, which notes: 'traditional accounting has necessarily remained focused on tangible assets. Traditionally, the only intangible assets recognized in financial statements have been intellectual property, such as patents and trademarks where a market value has been established by a transaction, and acquired items such as goodwill. Although accounting standards can probably be developed further to take into account a wider range of intangibles, clear limits are set by the difficulty of establishing monetary values (valuation) that are at the same time consistent across firms, verifiable and that cannot be easily manipulated. As a result, a significant portion of corporate assets go under-reported in the financial accounts. The relative lack of accounting recognition of intangibles coupled with their growing importance in the value creation process means that the financial statements have lost some of their value for shareholders. If other information does not fill the void, there could be misallocation of resources in capital markets'. See also Blair and Wallman (2001).
} 
by companies worldwide and sometimes audited by specialized consulting firms (KPMG, 2008).

In conclusion, improved entity-specific methods appear to be best suited to recognizing and accounting for intangibles resources while still fulfilling the principal objectives of auditing and enforcing public information disclosure. Intangibles may then be recognized and accounted for through the capitalization of bundles of imputable monetary outflows (expenditures), supplementary systems of non-monetary measurements and trustworthy disclosure of narrative information. This inside-related information may require a special control environment if it is to be disclosed and audited in a reliable and consistent way. In particular, and this is the crucial point we shall discuss in the following section, the certification of such information disclosure necessarily requires some firm-specific expertise on the part of directors.

\section{BOARD INDEPENDENCE AND FIRM-SPECIFIC EXPERTISE: THE TRADE-OFF}

Under the 'decision usefulness paradigm', the performance of the accounting process should be evaluated according to the degree of correspondence between required and disclosed information. This performance is a function of the system of disclosure, which includes the accounting standards and the actors having ultimate responsibility for certifying the financial statements. Accordingly, company directors have a crucial role to play in enhancing the overall quality of financial and non-financial reporting (Cohen, Krishnamoorthy and Wright 2004). In turn, this may improve the accuracy of financial decision-making by investors and shareholders.

As part of its monitoring role, including the validation of financial and non-financial reporting, an essential attribute for a Board is the propensity of its members not to collude with corporate executives - that is to be 'objective' (Boot and Macey 2004). Of course, objectivity is ultimately a subjective disposition. However, distant shareholders and other external stakeholders, as well as regulators, need to be able to rely on clearcut proxies. Accordingly, the basic idea common to a number of existing definitions of independence is to identify some objective criteria that minimize the conflict of interests between directors and corporate officers. Generally speaking, independence is assumed to be compromised if the director of a company $(i)$ is, or has been, a corporate executive 
of that company or of its affiliates, (ii) is, or has been, employed by that company or by its affiliates, (iii) is employed as an executive of another company where any of that company's executives sit on the Board, (iv) is a large block-holder of that company or (v) has a significant business relationship with that company or its affiliates. On this basis, directors are usually divided into three groups according to their relative degree of independence (Clarke 2007). Executive or inside directors are corporate executives. Affiliated or gray directors are not executives, but they do not meet one of the previous criteria; this category encompasses in particular employees, long-term block-holders or investment bankers in relation with the company. Finally, independent directors are outsiders that fulfil the whole set of criteria.

As a general proposition, de jure independence is supposed to foster 'objectivity', which in turn increases the probability of sanctions being imposed on imprudent or underperforming managers. Following this approach, Ferreira, Ferreira and Raposo (2008) define independence as the probability of a CEO being fired and replaced by the Board, once he or she has been judged by the stock market (or the Board itself) to be performing poorly. As far as certification is concerned, such a definition of independence ensures that directors will reject information they believe to be biased or incomplete and will make sure that appropriate market values have been used to evaluate corporate assets (Gordon 2007).

However, independence (even augmented with generic literacy in accounting and finance) can be the sole attribute determining the quality of disclosure when the information set to be certified comprises only market-driven information. As argued above (1.1), a not insignificant part of the relevant information set needed by investors is firm-specific $\left(y_{k}\right)$ and the quality of this soft information is intrinsically related to the characteristics of the actors that produce and certify it. Put differently, accounting figures are not, most of the time, subject to validation through market evidence. This is especially true for narrative information dealing with intangibles (see 2.2 above), as well as for 'forward-looking' information intended to identify factors that may influence a firm's future performance and position. However, it is also true for pure historical cost accounting: the appropriate identification, classification and imputation of expenditures to related intangible resources requires a specific knowledge of the context and processes that have been put in place inside the firm to develop and maintain these resources. 
Whenever firm-specific information is disclosed, the economic usefulness of the certification by the Board depends on the ability of its members to actually understand the main features of the business model. And this cognitive aptitude is less related to a generic expertise in accounting and finance than to specific knowledge of that business over time (Lanfranconi and Robertson 2002). When directors do not have any particular firm-specific expertise, then their certification becomes purely formal, acquiring economic significance only as such expertise is developed.

Thus trustworthy certification requires both a willingness to refuse accreditation of biased or narrow reports and the ability to gather and assess firm-specific information. As a consequence, the overall quality of control over information disclosure increases the more independent directors are and the more firm-specific expertise they have.Yet, while there is no reason to posit that generic expertise is negatively linked to de jure independence, things are different for firm-specific expertise. As the previous definition makes clear, application of the standard criteria used to define independence in practice result in putting a distance between the firm and its directors so as to minimize potential conflict of interests with executive management. In turn, this distance tends to reduce the directors' ability to acquire and assess firm-specific knowledge. By contrast, being part of the firm (as executives and non-executive employees are) or being in close connection with it (as investment bankers, large block-holders and representatives of main stakeholders are) provides some noticeable advantages in dealing with firmspecific information. It is widely recognized that independent (outside) directors are at a cognitive disadvantage over non-independent (insider) directors (see e.g. Baysinger and Hoskisson 1990, p.74; Klein 1998, p. 278; Osterloh and Frey 2006). This disadvantage may, in some circumstances, undermine the overall monitoring performance of a purely independent Board. For instance, appointing an independent director (an academic lawyer in corporate governance, for example) to the Board of a listed bio-technology firm is like appointing an economist to the panel examining a doctoral thesis on theological aesthetics. While the economist will surely be objective (i.e. impartial in disputes between scholars of theological aesthetics), one may seriously doubt his or her ability properly to assess the candidate's overall quality.

Another way to express the argument is to distinguish between de jure (formal) independence and genuine (substantive) independence. Because of the cognitive 
disadvantage they have over insiders, de jure independent directors have to rely on the information provided by the firm's executive management to fulfil their monitoring role (McNulty and Pettygrew 1999). This reliance actually limits directors' real independence, i.e. the ability to monitor objectively. By contrast, firm-specific expertise, in the sense of a deeper business understanding, may increase real independence (Hooghiemstra and van Manen 2004; Wagner 2008).

To sum up, independence offers decisive advantages in terms of control, but it also has an opportunity cost in that it reduces a Board's ability to cope with entity-specific information. Accordingly, it can reasonably assumed that there is a fundamental tradeoff between de jure independence and firm-specific expertise that will determine an optimal level of independence ${ }^{12}$.

The following economic model aims to capture the basic functioning of this trade-off. For simplicity's sake, let us assume that each Board member is either a firm-specific expert (defined as $e$ ) or independent (defined as $i$ ). Normalizing the size of the Board to one, we have:

$$
i=1-e \in(0 ; 1)
$$

where $i$ is the relative share of independent Board members.

Furthermore, let us assume that the firm is characterised by a given relative presence of intangible resources that do not have a market basis for accounting and disclosure. This degree $k$ is normalised to one. Moreover, let us assume that $k \geq e$. This simply implies that the Board's knowledge or expertise is never complete.

In this framework, the total agency cost related to the Board acting as certifier may be defined as

$$
B(i, e, k) \equiv W(i, e)+D(i, k)+C(e, k)+M(e, k)
$$

\footnotetext{
${ }^{12}$ Ferreira et al (2008) propose a model in which shareholders optimize on the level of independence. They also argue that the main advantage of independence is to make sure that a 'bad' CEO will be fired. However, the tradeoff they propose is different from ours: in their model, independence has a monetary cost that is borne by shareholders (due to dispersed ownership in particular). In our model, the cost of independence is non-monetary: it is the reduced ability of directors to acquire and certify firm-specific information. A further difference might be pinpointed: while the Board's ability to identify a bad CEO is exogenous in their model, our analysis suggests that this ability is endogenous. In particular, it decreases as de jure independence increases.
} 
Or, equivalently,

$$
B(i, k) \equiv W(i, 1-i)+D(i, k)+C(1-i, k)+M(1-i, k)
$$

In particular:

- $\quad W(i, e)$ is the fixed cost of the Board incurred as a result of the remunerations $\left(w_{i}, w_{e}\right)$ paid to its members $(i, e)$. Its derivative is increasing (or null) in $i$ when the independent member remuneration is higher than the expert member remuneration $\left(W_{I}{ }_{I} \geq 0\right.$ if $\left.w_{i} \geq w_{e}\right)$, and decreasing in $i$ otherwise $\left(W^{\prime}{ }_{i}<0\right.$ if $\left.w_{i}<w_{e}\right)$. Analytically, a generic function denotes this cost as follows:

$$
W(i, 1-i)=w_{i} \cdot i+w_{e} \cdot e
$$

where $W_{i}^{\prime}, W^{\prime}{ }_{e}>0$.

- $\quad D(i, k)$ is the ignorance cost of the Board relative to its level of independence. It arises because independent members lack the ability to discover, understand and certify relevant non-market, entity-specific information $(k)$. According to the previous discussion, the higher the level of $k$ for a given level of $i$, the lower the Board's ability to understand and monitor management behaviour (analytically, the derivative is then increasing in $k: D^{\prime}{ }_{k}>0$ ); and the higher the Board's level of independence $(i)$, the less able it is to understand a given $k$ (analytically, the derivative is increasing in $i: D_{i}>0$ ). Furthermore, let us assume: $D(i, 0)=O$ (i.e. if there is no entity-specific information, then no ignorance cost will arise for any $i$ ); and $D(0, k)=0$ (i.e. if the Board comprises only experts, then, by definition, no ignorance cost will arise for any $k$ ). Analytically, this cost may be described as follows:

$$
D(i, k)=d \cdot i \cdot k
$$

where $d>0$ and $D^{\prime}{ }_{i}, D^{\prime}{ }_{k}>0$.

- $\quad C(e, k)$ is the Board's perking (collusion) cost relative to its level of entityspecific expertise. It arises because the need for specific expertise makes it necessary to appoint insiders to the Board whose position obviously makes it easier for them than for independent members to collude with management. It is possible to rewrite this function as $C(1-i, k)$. Its derivative is decreasing in $i: C^{\prime}{ }_{i}<0$ (i.e. the higher $i$ is, the lower the 
perking cost is), and increasing in $k: C^{\prime}{ }_{k}>0$ (i.e. the higher $k$ is, the greater the opportunity to collude becomes). Furthermore, let us assume: $C(e, 0)=0$ (i.e. if there are no entity-specific information, then no perking costs arise for any $e$ : there is no specific information to be hidden); and $C(0, k)=0$ (i.e. if the Board comprises only independent members, then, by definition, no perking cost arises for any $k$ ). Analytically, this cost may be described as follows:

$$
C(e, k)=c \cdot e \cdot k
$$

where $c>0$ and $C^{\prime}{ }_{e}, C^{\prime}{ }_{k}>0$.

- $\quad M(e, k)$ is the Board's supplemental monitoring cost relative to its independence. It arises because independent directors may need to hire professional consultants and auditors to assist them; the cost of hiring external experts therefore constitutes the opportunity cost of maintaining a higher level of independence. According to the previous discussion, the higher the value of $k$, the greater the accumulated cost of these external advisors required to cope with $k$ (analytically, the derivative respect to $k$ is positive: $\left.M_{k}^{\prime}>0\right)$. Furthermore, the higher the share of experts on the Board $(e)$, the lower the monitoring cost becomes (i.e. the derivative respect $e$ is negative: $M_{e}^{\prime}<0$ ). Finally, when $e=k$, then $M(k, k)=0$ : when $e$ reaches the maximum value, then there is no need to hire professional consultants and the opportunity cost is zero. Analytically, this cost is described as follows:

$$
M(e, k)=\frac{1}{2} \cdot m \cdot(k-e)^{2}
$$

where $m>0$ and $M^{\prime}{ }_{k}>0, M_{e}^{\prime}<0$, with $k \geq e$.

Accordingly, the total agency cost of the Board may be denoted as follows:

$$
B(i, e, k)=\left(w_{i}-w_{e}\right) \cdot i+w_{e}+(d-c) \cdot i \cdot k+c \cdot k+\frac{1}{2} \cdot m \cdot(k-1+i)^{2}
$$

Efficiency requires this total cost $B(i, e, k)$ to be minimized for each level of entityspecific information $(k)$. Figure 1 comprises two graphs: graph 1 denotes the cost curve for each level of $k$; graph 2 denotes the corresponding locus of optimal values for $\left(i *, k^{*}\right) .^{13}$

\footnotetext{
${ }^{13}$ This graph describes a simulation of the model when $w_{i}=w_{e}=1, m=4, d=2, c=3$. Different parameter values will not alter the main results.
} 
In graph (1), the $\mathrm{y}$-axis represents the total cost $B(i, k)$ and the $\mathrm{x}$-axis the level of independence of the Board ( $i)$. Each curve identifies the value of $B(i, k=$ given) and shows how such cost changes for each level of $i$ when $k$ is given. When $k$ increases, the cost function $B(i, k)$ is identified by escalating curves.

For a given level of entity-specific information $(k)$, it is possible to identify an optimal level of Board independence that minimizes the cost function $B(i, k)$. Since higher $k$ implies descending cost curves, then the optimal level of $i$, given by $B^{\prime}{ }_{i}\left(i, k^{*}\right)=0$, is a decreasing function of $k$. This decreasing function identifies the trade-off between entity-specific information $(k)$ and Board independence $(i)$. Solving the minimization of the cost function $B(i, e, k)$ for each value of $k$, we obtain the $i$ - $k$ trade-off function:

$$
i=1-\frac{\left(w_{i}-w_{e}\right)+(d-c+m) k}{m}
$$

This means that the higher the entity-specific information $(k)$ is, the lower the optimal level of Board independence $(i)$ becomes. Our analysis then predicts that the optimal proportion of (de jure) independent Board members decreases as the importance of intangible resources in corporate performance increases. This relation between $k$ and $i$ depends on the parameters. In particular, the optimal level of independent directors is lower when:

- $\quad w_{i}$ is higher then $w_{e}$;

- $\quad d$ is higher than $c$ (i.e. the ignorance cost is higher than the perking cost);

- $\quad m$ is higher (i.e. higher cost to hire external experts).

Graph (2) shows the $i$ - $k$ trade-off function. When the level of intangible resources $(k)$ is zero, the optimal level of Board independence $(i)$ is one: all members of the Board should be independent. Furthermore, $i=1$ implies $e=0$ and no perking cost arises. Finally, $k=0$ implies that there is no specific information to discover: the ignorance cost is zero. When $k$ increases, for example when the management of the firm develops innovative practices, products or technologies, the relevant level of entity-specific information increases and a fully independent Board $(i=1)$ is no longer able to discover and properly certify the new 'information set' alone. A trade-off between $i$ and $k$ arises. If the composition of the Board does not change, the agency cost will increase because $k$ 
is higher. On the one hand, the ignorance cost increases $\left(D^{\prime}{ }_{k}>0\right)$; on the other hand, the independent Board has to hire professional experts to compensate for its ignorance regarding entity-specific information $k\left(M_{i}^{\prime}=-M_{e}^{\prime}>0\right)$. The more $k$ increases, the higher the cost of maintaining a fully independent Board. At some point $k_{0}$ (depending on parameters), a fully independent Board becomes inefficient: for each $k>k_{0}$, cost minimization requires that some independent Board members should be replaced by expert members. This new Board composition leads to lower monitoring costs (since expert members have a better understanding of the entity-specific information), even though this increases the likelihood of additional perking costs (which increase in $e$ : $\left.C^{\prime}{ }_{e}>0\right)$.

Generally speaking, the trade-off implies an optimal Board composition with a mix of expert and independent members. The precise optimal share depends on the changing characteristics of the industry and the business (captured by parameters). Beyond a certain level of independence, further increases may undermine the Board's overall ability to exercise effective control over the firm. Thus excessive independence may have adverse consequences and ultimately damage the firm's performance.

By contrast, non-independent grey or affiliated directors, whose position involves firmspecific expertise, have some attractive attributes that serve to enhance the efficiency of corporate control and the overall quality of corporate disclosure. This is particularly the case with (non-executive) employee representatives (on this point, see also Osterloh and Frey 2006). On the one hand, they have long-term relationships with the firm - a convenient way to develop firm-specific expertise - while their interests remain a priori distinct from those of the executive managerial team. On the other hand, workforce training in firm-specific capabilities and labor organization are two of the main components of intangible performance drivers: Corrado et al (2006) estimate in the US case for the period 1995-2003 that investments aimed at enhancing human resources (training, labor organization including strategic planning) accounted for one third of total investment in intangible assets. Furthermore, while they observe that, for the same period, investments in intangibles accounted for $27 \%$ of the annual growth, they note that the contribution of training and organizational innovation amounts to one third of this $27 \%$. Thus the inclusion of employee representatives on the Board may enhance its ability to cope with firm-specific information and intangibles, especially those related to human capital. This analysis is consistent with the empirical evidence provided by Fauver and Fuerst (2006), who show that the inclusion of worker representatives on the 
(supervisory) Boards of German firms is positively correlated (up to a certain point) with the performance of those firms.

\section{CONCLUSION}

This article has dealt with the quality of financial reporting as a crucial component of efficient corporate control and share market pricing. The investigation has focused on the role of the Board of directors. We have shown that firm-specific expertise may be an important attribute for directors when the relevant information set for investors and shareholders includes so-called 'firm-specific' information. This is particularly true whenever intangibles are significant drivers of performance, such as in high-tech and innovative industries. Yet we argue that there is a trade-off between this kind of expertise and the de jure independence that is commonly advocated by institutional investors and policy-makers. Consequently, more (de jure) independence is not always desirable: there is an optimal share of independent Board members that decreases as the importance of intangible resources increases. In sum, our analysis points to the attractiveness of pluralistic Board appointments involving (de jure) independent members, affiliated members and stakeholder representatives with specific knowledge of the business. Conversely, our analysis cautions against 'super' or 'full majority' Boards, except when business performance depends solely on a simple set of separable tangible resources.

In terms of future researches, our analysis points toward two directions. Regarding corporate governance per se, and more precisely the Board, empirical analysis relating board composition to the specific attributes of firms (in particular importance and type of intangible assets) is needed. And while (de jure) independence is an important parameter of board composition, our analysis calls for further investigation on the cognitive aptitude of directors, through identification of proxies (education, other mandates, prior and current job experience, etc.) for firm-specific and generic expertise (see in this direction Masulis and Mobbs, 2009). Regarding accounting theory and practice, our analysis demonstrates that the growing importance of intangible resources should lead to a careful (re)consideration of non-market basis for accounting, such as improvement on historical cost accounting systems. In any case, this re(consideration) should be strongly grounded in the economic theory (of the firm), as recognised by Coase (1990). 


\section{REFERENCES}

Anthony, Robert, Newton (2004), Rethinking the rules of financial accounting. Examining the rules for proper reporting, McGraw-Hill, USA.

Antonelli, Cristiano (2001), The Microeconomics of Technological Systems, Oxford University Press, Oxford.

Barberis, Nicholas and Richard Thaler (2003), "A survey of behavioral finance," in Constantinides, George, Milton Harris and René Stultz. (eds.) Handbook of the Economics of Finance, Elsevier Science Publishers, Amsterdam, The Netherlands, pp.1054-1123

Baysinger, Barry and Robert Hoskisson (1990), "The composition of boards of directors and strategic control: Effects on corporate strategy", Academy of Management Review, vol.15 (1), pp.72-87.

Berle, Adolf Augustus, Jr. and Gardiner Means (1932), The Modern Corporation and Private Property, Harcourt, Brace and World, New York, new ed. 1967.

Bhagat, Sanjai and Bernard S. Black (1999), "The uncertain relationship between Board composition and firm performance", Business Lawyer, vol.54, pp.921-963.

Bhagat, Sanjai, Brian Bolton and Roberta Romano (2008), "The Promise and Pitfalls of Corporate Governance Indices," Columbia Law Review, vol.108 (8), pp.1803-1882.

Black, Sandra E. and Lisa M Lynch. (2001), "How to Compete: the Impact of Workplace Practices and Information Technology on Productivity", Review of Economics and Statistics, 83 (3), pp.434-445.

Blair, Margaret and Steven MH Wallman (2001) dir., Unseen Wealth. Report of the Brookings task force on Intangibles, Brookings Institution Press, Washington D.C.

Boot, Arnoud W.A. and Jonathan R. Macey (2004), "Monitoring corporate performance: the role of objectivity, proximity, and adaptability in corporate governance", Cornell Law Review, vol.89, pp.356-393.

Brealey, Richard A. and Stewart C. Myers (2005), Principle of Corporate Finance, McGraw Hill, 7 ed.

Bresnahan, Timothy, Erik Brynjolfsson and Lorin M. Hitt, (2002), "Information Technology, Workplace Organization and the Demand for Skilled Labor: Firm-level Evidence", Quarterly Journal of Economics, 117 (1), pp.339-376.

Brown, Robert, Jr. , (2007), "Corporate Governance, the Securities and Exchange Commission, and the Limits of Disclosure", Catholic University Law Review, vol.57, pp.45-92.

Caroli, Eve, and John Van Reenen (2001), "Skill Biased Organizational Change? Evidence from a Panel of British and French Establishments", Quarterly Journal of Economics, 116 (4), pp.1449-1492 
Clarke, Donald (2007), "Three Concepts of the Independent Director", Delaware Journal of Corporate Law, vol.32 (1), pp.73-111.

Coase, Ronald (1990), “Accounting and the Theory of the Firm”, Journal of Accounting and Economics, vol.12, pp.3-13. Reprinted in Yuri Biondi, Arnaldo Canziani and Thierry Kirat (2007) eds., The firm as an entity: implications for economics, accounting, and law, Routledge, New York and London, pp.73-81.

Cohen, Jeffrey R, Ganesh Krishnamoorthy and Arnold Wrigh (2004), "The Corporate Governance Mosaic and Financial Reporting Quality", Journal of Accounting Literature, pp.87-152.

Corrado, Carol, Charle Hulten and Daniel Sichel (2006), "Intangible Capital and Economic Growth", NBER working paper, $\mathrm{n}^{\circ} 11948$.

Cunningham, Lawrence A. (2007), "Rediscovering Board Expertise: Legal Implications of the Empirical Literature", GWU Law School Public Law Research Paper No. 363. Available at SSRN: http://ssrn.com/abstract=1024261

Dalton, Dan R., Catherine M. Daily, Alan E. Ellstrand, and Jonathan L. Johnson. (1998), "Metaanalytic reviews of board composition, leadership structure and financial performance", Strategic Management Journal, vol.19, pp.269-290.

Eckstein, Claire (2004), "The measurement and recognition of intangible assets: then and now", Accounting Forum, vol.28, pp.139-158.

Fama, Eugene (1970), "Efficient capital markets: A review of theory and empirical work," Journal of Finance, vol. 25, n², pp.383-417.

Fauver, Larry and Michael E. Fuerst (2006), "Does Good Corporate Governance Include Employee Representation? Evidence from German Corporate Boards", Journal of Financial Economics, vol.82, pp.673-710.

Ferreira, Daniel, Miguel Ferreira, and Clara C. Raposo (2008), "Board Structure and Price Informativeness" (April 2007). EFA 2008 Athens Meetings Paper (former ECGI Finance Working Paper No. 160/2007), available at: http://.com/abstract=983524

Gordon, Jeffrey N. (2007), "The Rise of Independent Directors in the United States, 1950-2005: Shareholder Value and Stock Market Prices", Stanford Law Review, 59 (6), pp.14651568.

Griliches, Zvi (1994), "Productivity, R\&D, and the data constraint", American Economic Review, 84 (1), March, pp.1-23.

Hitz, Joerg-Markus (2007), "The Decision Usefulness of Fair Value Accounting - A Theoretical Perspective", European Accounting Review, vol.16, n², pp.323-362.

Hooghiemstra, Reggy and Jaap van Manen (2004), "The Independence Paradox: (Im)possibilities Facing Non-executive Directors in the Netherlands", Corporate Governance: an International Review, vol.12(3), pp.314-324. 
IASB (2005), "Measurement Bases for Financial Accounting. Measurement on Initial Recognition", Discussion Paper, London.

Ijiri, Yuji (1967) The Foundations of Accounting Measurement: A Mathematical, Economic and Behavioral Inquiry, Englewood Cliffs, Prentice-Hall, N.J., USA.

Johnson, Jonathan L. , Catherine M. Daily and Alan E. Ellstrand (1996), "Boards of directors: A review and research agenda", Journal of Management, vol.22, pp.409-438.

Kim, YoungGak (2007), "A Survey on Intangible Capital”, CEI Working Paper Series, No. 2007-10, Institute of Economic Research, Hitotsubashi University, December.

Klein, April, (1998), "Firm Performance and Board Committee Structure", The Journal of Law and Economics, vol.16, pp.275-303.

Klein, Peter, Daniel Shapiro and Jeffrey Young (2005), "Corporate Governance, Family Ownership and Firm Value: The Canadian Evidence", Corporate Governance: An International Review, vol.13(6), pp.769-784.

KPMG (2008), International Survey of Corporate Responsibility Reporting, KPMG International, The Netherlands.

Lanfranconi, Claude P. and Darroch (Rick) A. Robertson (2002), "Corporate financial reporting: The role of the board of directors", Ivey Business Journal, September/October.

Lev, Baruch (2001), Intangibles: Management, Measurement and Reporting, Brookings Institution Press, Washington D.C.

Lintner, John (1965), "The valuation of risk assets and the selection of risky investments in stock portfolios and capital budgets," Review of Economics and Statistics, vol.47, n¹, pp.13-37.

Lynch, Lisa M.. and Sandra Black (1998), "Determinants of Employer-Provided Training", Industrial \& Labor Relations Review, 52 (1), pp.64-80.

Malkiel, Burton G. (1992), "Efficient Market Hypothesis", The New Palgrave Dictionary of Money and Finance, pp.739-744.

Masulis, Ronald W. and Mobbs, H. Shawn (2009), "Are All Inside Directors the Same? Do They Entrench CEOs or Facilitate More Informed Board Decisions?", ECGI - Finance Working Paper No. 241/2009, http://ssrn.com/abstract=1108036

McNulty, Terry and Andrew Pettigrew (1999), "Strategists on the Board", Organizations Studies, vol.20, pp.47-74

Nakamura, Leonard (2003), “The Rise in Gross Private Investment in Intangible Assets since 1978”, Federal Reserve Bank of Philadelphia, mimeo.

OECD (2006), Intellectual assets and value creation: Implications for corporate reporting, Corporate Affairs Division, Directorate for Financial and Enterprise Affairs, 10 December, Paris. <http://www.oecd.org/daf/corporate-affairs/>.

Osterloh, Margit and Bruno Frey (2006), "Shareholders Should Welcome Knowledge Workers as Directors", Journal of Management and Governance, vol.10(3), pp.325-345. 
Petersen, Mitchell A. (2004), "Information: Soft and Hard", mimeo. http://www.kellogg.northwestern.edu/faculty/petersen/htm/papers/softhard.pdf

Roberts John Dominic, Therry McNulty and Philip Stiles (2005), "Beyond Agency Conceptions of the Work of the Non-Executive Director: Creating Accountability in the Boardroom", British Journal of Management, vol.16, pp.S5-S26.

Scicchitano, Sergio (2007). "On the complementarity between on-the-job training and R\&D: a brief overview", Economics Bulletin, vol. 15(2), pp.1-11.

Sharpe, William (1964), "Capital asset prices: A theory of market equilibrium under conditions of risk," Journal of Finance, vol.19, n³, pp.425-442.

Shleifer, Andrei (2000), "Inefficient Markets: An Introduction to Behavioral Finance," Oxford University Press, New York.

Shubik, Martin (1993), "Accounting and its relationship to general equilibrium theory", Economic Notes, vol.22(2), pp.226-234. Reprinted in Yuri Biondi, Arnaldo Canziani and Thierry Kirat (2007), eds., The firm as an entity: implications for economics, accounting, and law, Routledge, New York and London, pp.73-81.

Stein, Jeremy C. (2002), "Information Production and Capital Allocation: Decentralized versus Hierarchical Firms", The Journal of Finance, vol.57, n5, pp.1891-1921.

Stout, Lynn A. (2003), "The Mechanisms of Market Inefficiency", Journal of Corporation Law, vol.28, pp.635-669.

Sunder Shyam (2002), "Knowing What Others Know: Common Knowledge, Accounting, and Capital Markets", Accounting Horizons, vol.16, n²4, pp.305-318.

Villalonga, Belén. (2004), "Intangible resources, Tobin's Q, and sustainability of performance differences", Journal of Economic Behaviour and Organization, vol.54, pp.205-230.

Wagner, Alexander F. (2008), "Board Independence and Competence", Swiss Finance Institute Research Paper No. 07-17. Available at SSRN: http://ssrn.com/abstract=1001206 
Figure 1 - The Board cost and the trade-off between independence and firmspecific expertise

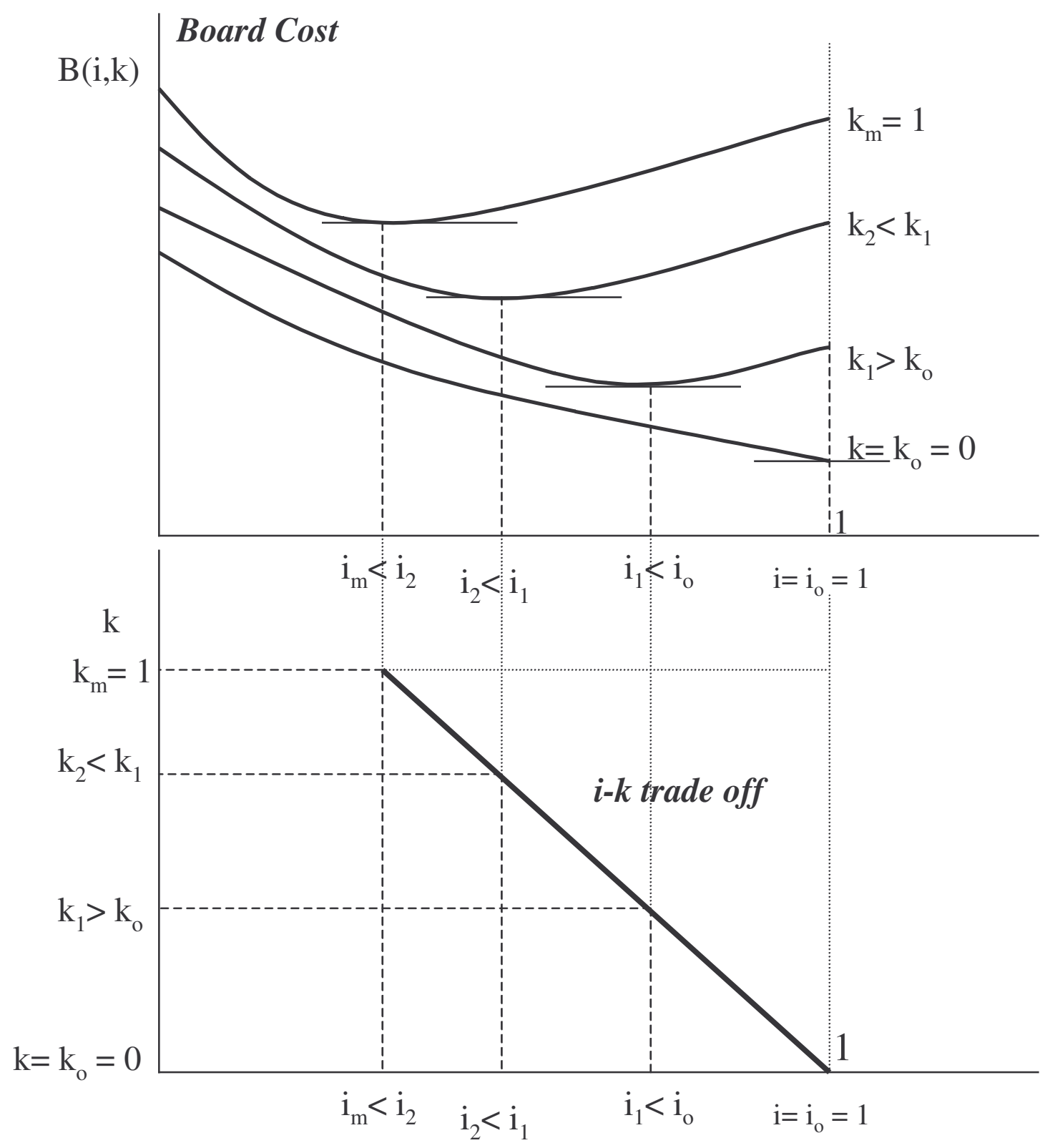

